\title{
Nutritional behavior in pregnancy
}

\author{
Natalia Misan ${ }^{1}$, Katarzyna Paczkowska², Magdalena Szmyt ${ }^{2}$, Katarzyna Kapska ${ }^{1}$, \\ Lidia Tomczak ${ }^{1}$, Grzegorz H. Breborowicz ${ }^{1}$, Mariola Ropacka-Lesiak ${ }^{1}$ \\ ${ }^{1}$ Department of Perinatology and Gynecology, Poznan University od Medical Sciences, Poland \\ 2Students' Scientific Association by the Department of Perinatology and Gynecology, \\ Poznan University od Medical Sciences, Poland
}

\begin{abstract}
Objectives: The aim of the study was to characterize nutritional behavior in pregnancy.

Material and methods: The survey study included 250 pregnant women. The survey concerned dietary behavior reffered to the type of diet, the number of meals per day, snacking between meals, consumption of meat, fish, dairy products, bread, fruits and vegetables.

Results: $88.8 \%$ of the respondents were not on a special diet. The most of the women ate more than three times a day. The women usually ate fruits and vegetables, yogurt and sweets as snacks between meals. The majority of respondents consumed meat and sliced meats twice or once a day with the preference of poultry. Only $17.6 \%$ of them ate fish with the recommended frequency and as much as $21.2 \%$ chose not-recommended species. Almost $29.6 \%$ of patients consumed 3 to 4 servings of milk or milk products a day and $16.8 \%$ of them excluded milk. Half of the respondents declared eating wheat bread and $24 \%$ of them chose wheat roll during pregnancy. Despite the large number of women who consumed wheat baking, a considerable amount of women chose wholemeal bread and wholemeal rolls. Nutritional behaviors were correlated with on education level and weight gain during pregnancy.

Conclusions: The frequency of meals was adequate for the most of pregnant women as well as recommended consumption of meat with poultry preference. However, the inappropriate nutrition was also observed in a low consumption of fish and dairy products, a high consumption of wheat breadstuff and sweets, as well as in a small intake of milk. Education level and weight gain during pregnancy were associated with nutritional behaviors.
\end{abstract}

Key words: nutritional behavior; proper diet; eating habits; healthy lifestyle; body mass index; weight gain

Ginekologia Polska 2019; 90, 9: 527-533

\section{INTRODUCTION}

Proper nutrition in pregnancy is one of the public health concerning problem. The malnutrition affects more than a half of women in many low- and middle-income countries with the highest risk among the poorest [1].

Both among underweight as well as overweight women, the risk of small for gestational age fetuses (SGA) and prematurity is increased [2]. Moreover, maternal obesity can lead to many consequences such as pregnancy induced hypertension, preeclampsia, gestational diabetes, increased rate of cesarean sections and delivering large for gestational age infants (LGA) [3].

Leonard SA. et al. reported that high maternal body weight in the reproductive period increases the risk of childhood obesity. Furthermore, the high pre-pregnancy
$\mathrm{BMI}$ influences more on the postpartum weight retention than weight gain during pregnancy [4].

According to the Academy of Nutrition and Dietetics statement, reproductive-aged women should implement a healthy lifestyle, which reduces the risk of fetal defects, inappropriate fetal development and chronic diseases of both mother and newborn. The factors affecting the perinatal outcomes include correct pre-pregnancy weight, appropriate weight gain and physical activity during gestation, consumption of a wide variety of food, vitamins and minerals supplementation, elimination of alcohol and smoking [5].

\section{Objectives}

The aim of the study was to characterize nutritional behavior in pregnant women in Poland. 


\section{MATERIAL AND METHODS}

The survey study included 250 women who gave birth in the Obstetric-Gynecological Hospital, University of Medical Sciences in Poznan. All patients signed informed consent and fulfilled a questionnaire prepared by authors (Supp. file 1). Then the women were divided into two groups- those with lower and higher education level and the nutritional behaviors were analyzed. Independently, they were divided for three groups according to pre-pregnancy BMI and gestational weight gain recommended by the Institute of Health [6]. The first group was composed of women with lower weight gain than recommended, the second group consisted of females with proper weight gain and the third group included respondents who put on weight more than recommended.

The questions referred to general information, such as age, pregestational and actual weight, place of residence, education, marital status, employment before and during pregnancy, the period of working during pregnancy and the type of pregnancy (singleton or multiple). Moreover, the questions also concerned diseases and complications during pregnancy. The part of dietary behaviours referred to the type of diet and the number of meals per day. It also concerned snacking between meals, consumption of meat, fish, dairy products, bread, fruits and vegetables.

The general characteristics of the study group is presented in the Table 1. The coexisting diseases and pregnancy complications are shown in the Table 2. The data are expressed as a percentage or as mean (M) and standard deviation (SD).

The calculations were performed using Microsoft Excel 2010 and Statistica StatSoft 13.1. The data in interval scale were assessed using nonparametric Mann-Whitney test and the data in nominal scale were analyzed using the Fisher's exact test. The significance level was assumed as $p$-value below 0.05 . The data do not add up because of multiple choice questions.

\section{RESULTS}

$88.8 \%$ of the respondents were not on any special diet. Only $7.2 \%$ of women were on diabetic diet and $0.8 \%$ on gluten-free diet. The same number of women were on low-salt diet and $0.4 \%$ on low-fat diet. Only $1.2 \%$ of pregnant women were vegetarians or vegans. High protein food responded $0.8 \%$ women. When assessing the frequency of meals, it was noticed that only $33.6 \%$ of women ate 5 times a day or more often. Pregnant women consumed meals 4 (36.0\%) or $3(26.0 \%)$ times a day, and up to $4.4 \%$ ate less than 3 times a day. Especially often they ate fruits and vegetables (84.8\%) and yoghurt (68.8\%). Almost half of them ate sweets (46.8\%) between meals. According to fruits and vegetables, the most often chosen were apples, bananas, oranges, and among vegetables tomatoes, carrots, cucumber and potatoes.

\begin{tabular}{|c|c|}
\hline Characteristics & $\begin{array}{l}\text { Pregnant } \\
\text { women }\end{array}$ \\
\hline Age [years] (Mean \pm SD) & $30 \pm 5$ \\
\hline BMI $\left[\mathrm{kg} / \mathrm{m}^{2}\right]($ Mean \pm SD) & $22.8 \pm 4.4$ \\
\hline $\begin{array}{l}\text { Place of residence [\%] } \\
\text { rural areas } \\
\text { urban areas }\end{array}$ & $\begin{array}{l}33.2 \\
66.8\end{array}$ \\
\hline $\begin{array}{l}\text { Education [\%] } \\
\text { lower } \\
\text { higher }\end{array}$ & $\begin{array}{l}29.2 \\
70.8\end{array}$ \\
\hline $\begin{array}{l}\text { Marital status [\%] } \\
\text { unmarried } \\
\text { married } \\
\text { divorced }\end{array}$ & $\begin{array}{c}16.0 \\
81.2 \\
2.8\end{array}$ \\
\hline $\begin{array}{l}\text { Work activity }[\%] \\
\text { before pregnancy } \\
\text { during pregnancy }\end{array}$ & $\begin{array}{l}86.4 \\
59.6\end{array}$ \\
\hline $\begin{array}{l}\text { Term of gestational work activity discontinuation } \\
\text { [weeks] (Mean } \pm \text { SD) }\end{array}$ & $20 \pm 10$ \\
\hline $\begin{array}{l}\text { Type of pregnancy [\%] } \\
\text { singleton } \\
\text { multiple }\end{array}$ & $\begin{array}{c}91.2 \\
8.8\end{array}$ \\
\hline
\end{tabular}

Table 2. The diseases and pregnancy complications of survey respondents

\begin{tabular}{|l|c}
\hline Diseases and pregnancy complications & $\begin{array}{c}\text { Number of } \\
\text { pregnant } \\
\text { women [\%] }\end{array}$ \\
\hline
\end{tabular}

\begin{tabular}{|l|l|}
\hline Chronic arterial hypertension & 4.4 \\
\hline
\end{tabular}

\begin{tabular}{|l|l|l|l|l} 
Pregnancy induced arterial hypertension & 4.4
\end{tabular}

\begin{tabular}{l|l}
\hline Gestational diabetes mellitus & 9.6
\end{tabular}

\begin{tabular}{|l|l|}
\hline Anaemia & 7.6 \\
\hline
\end{tabular}

\begin{tabular}{|l|l|}
\hline Hypothyroidism & 8.4 \\
\hline
\end{tabular}

\begin{tabular}{l|l} 
Hyperthyroidism & 1.2 \\
\hline
\end{tabular}

\begin{tabular}{l|l} 
Polyhydramnion & 2.0 \\
\hline
\end{tabular}

\begin{tabular}{|l|l|}
\hline Oligohydramnion & 2.0 \\
\hline
\end{tabular}

\begin{tabular}{|l|l|}
\hline Premature membrane rupture & 4.0
\end{tabular}

\begin{tabular}{|l|l|}
\hline Intrauterine growth restriction & 3.6 \\
\hline
\end{tabular}

\begin{tabular}{|l|r|}
\hline Fetal defect & 2.0 \\
\hline
\end{tabular}

\begin{tabular}{l|l} 
Cervical insufficiency & 4.8 \\
\hline
\end{tabular}

\begin{tabular}{|l|l|} 
Threatening preterm delivery & 18.8 \\
\hline
\end{tabular}

\begin{tabular}{|l|l|}
\hline Vaginal bleeding in pregnancy & 8.8 \\
\hline
\end{tabular}

$\begin{array}{ll}\text { Spine pain } & 30.4\end{array}$

The majority of respondents consumed meat and sliced meats twice $(38.8 \%)$ or once $(34.8 \%)$ a day. As for meat, most of them consumed poultry (73.2\%). Much less women consumed beef (13.2\%) and pork (8.8\%). Even less pregnant women ate veal $(3.2 \%)$ and rabbit meat $(0.4 \%)$ that are considered very healthy. Only $17.6 \%$ of women ate fish with the recommended frequency. $75.6 \%$ of them chose fish 
called "fish of best choices" (salmon, cod, zander, herring, pollock, hake, blue hake, trout, sole) and even $21.2 \%$ chose not-recommended species such as mackerel, panga, and tuna. The majority of women (65.6\%) consumed fish only once a week, and $12.4 \%$ did not eat fish at all. Almost 29.6\% of patients consumed three to four servings of milk or milk products a day. However, $16.8 \%$ of patients excluded milk completely. Half of the respondents declared eating wheat bread and $24 \%$ of them chose wheat roll during pregnancy. Despite the large number of women who consumed wheat baking, a considerable amount of women chose wholemeal bread (49.2\%) and wholemeal rolls (35.6\%).

The high-educated women ate significantly more often five ( $34 \%$ vs $12 \%, p=0.0002$ ) or more than five ( $8 \%$ vs $0 \%$, $\mathrm{p}=0.0068$ ) meals a day in comparison to women with lower education level. Additionally, women with lower education consumed two dishes a day statistically more often ( $7 \%$ vs $2 \%$, $\mathrm{p}=0.0491)$. The high-educated respondents declared eating vegetables ( $92 \%$ vs $74 \%, p=0.0002)$, yoghurt $(75 \%$ vs $55 \%$, $\mathrm{p}=0.0020)$, beef ( $18 \%$ vs $3 \%, \mathrm{p}=0.006)$ and "fish of best choices" ( $80 \%$ vs $64 \%, p=0.0096)$ significantly more often than the rest of respondents. Taking into account the frequency of meat consumption, high-educated respondents declared eating meat and sliced meats once a day (39\% vs $25 \%, p=0.0206$ ) significantly more often. Statistically the greater group of women with lower education consumed dairy products four or more times a day ( $15 \%$ vs $5 \%$, $\mathrm{p}=0.0107$ ) but they also declared significantly more often eating dairy products occasionally ( $10 \%$ vs $2 \%, p=0.0078$ ) or not eating at all ( $4 \%$ vs $0 \%, p=0.0242)$. The wholemeal bread $(59 \%$ vs $25 \%, p<0.0001)$ and wholemeal rolls $(40 \%$ vs $26 \%, p=0.0285$ ) were eaten significantly more often by high-educated women in comparison to those with lower education, who preferred wheat bread ( $66 \%$ vs $44 \%$, $p=0.0010)$. Considering fruits and vegetables, the respondents with higher education chose apples $(78 \%$ vs $63 \%, p=0.0123)$, raspberries ( $21 \%$ vs $8 \%, p=0.0077$ ), grapefruits ( $18 \%$ vs $5 \%, p=0,0077$ ), asparagus ( 14 vs $1 \%$, $p=0,0013$ ), tomatoes (76 vs $53 \%, p=0,0004$ ), onions ( 14 vs $5 \%, \mathrm{p}=0.0469)$ significantly more often but they also ate potatoes ( 35 vs $58 \%, p=0.0009$ ) and broccoli ( $28 \%$ vs $42 \%$, $\mathrm{p}=0.0175)$ statistically less often than those with lower education.

According to pre-pregnancy BMl and gestational weight gain the women with lower weight gain than recommended declared consumption of wheat bread $(62.8 \%$ vs $45.7 \%$, $\mathrm{p}=0.0329)$, watermelon ( $15.3 \%$ vs $4.3 \%, p=0.0250)$ and beef $(17 \%$ vs $6.6 \%, p=0.0410)$ significantly more often than women with proper weight gain. Moreover, the females, who put on weight too low than recommended declared significantly more often consumption of watermelon ( $15.3 \%$ vs $2.7 \%$, $\mathrm{p}=0.0448$ ) and statistically less often eating between meals
(1.2\% vs $8.1 \%, p=0.0462)$, consumption of $\operatorname{cod}(23.9 \%$ vs $43.6 \%, p=0.0250)$ and herring $(14.8 \%$ vs $33.3 \%, p=0.0167)$ than females with higher weight gain than recommended. Furthermore, women with higher weight gain ate herring (33.3\% vs $10.5 \%, p=0.0027)$ and avoided eating meat ( $10 \%$ vs $0 \%, p=0.0044)$ significantly more often than those with proper weight gain.

\section{DISCUSSION}

Proper nutritional behavior in pregnancy is important for the wellbeing of both mother and fetus, because well-balanced diet supports maternal health during gestation, delivery and breastfeeding [7-11]. Most of our respondents were not on a diet similar to the results observed by Mielnik [12]. A special type of diet was implemented mostly as a consequence of pregnancy complications, forcing them to change the diet.

The Institute of Medicine recommends eating of three meals and two or more snacks a day [13]. Siega-Riz et al. [14] observed that women, who consumed main meals and snacks less often, had a higher risk of preterm delivery. In our study, only $26 \%$ of females followed the recommendations and consumed three main meals a day. Moreover, the most of our respondents declared eating four (36\%) or five $(28 \%)$ meals a day. The similar results were obtained by Mielnik [12]. Furthermore, Pieszko et al. [15] observed the increasing frequency of consumed meals in comparison to the pre-pregnancy period.

In the study of Kobiołka et al. the most often eaten snacks between meals were fruits (80\%). Consecutively, pregnant women as snacks chose yogurt $(61 \%)$, sweets (54\%) and vegetables (19\%) [16], what was compatible with the results of our study.

During pregnancy, the main recommended source of animal protein should be lean meat and its products, skimmed milk and its products, as well as fish and eggs. The consumption of pork due to the high content of saturated fats should be limited [17]. The consumption of meat and its products allows to cover the increasing iron demand for the prevention of anaemia and preterm delivery $[18,19]$. According to Szostak-Węgierek and Cichocka [20] study, the pregnant women should consume one portion (about 150 grams) of poultry a day in the first trimester and one and a half servings of poultry a day in the second and third trimester, interchangeably with fish two to three times a week. In our study, most women followed the recommendations and consumed meat and sliced meats twice (38.8\%) or once (34.8\%) a day, which was comparable with results of Mielnik. Moreover, she presented a similar number of non-eating meats women as it was found in our study (3.4\%). Similarly to Mielnik's research, pregnant women preferred poultry [12]. 
During gestational period pregnant women should also eat fish meals. It is recommended to eat one portion of fish (about 150 grams) in the first trimester and one and a half portion of fish during the second and third trimester with the frequency of two to three times a week [20]. In accordance with the Food and Drug Administration recommendations [21], the pregnant women should consume two to three servings of fish of best choices a week or one serving of fish of good choices a week. Only about one fifth (17.6\%) of our patients ate fish with the recommended frequency. Moreover, even $21.2 \%$ of the respondents chose not-recommended species of fish. Kobiołka et al. [16] noticed that the majority of pregnant women consumed fish once or twice a week (74\%), three to four times a week (18\%) and $8 \%$ of them declared not eating fish at all.

Furthermore, it is recommended to consume three servings of milk or milk products a day in the first trimester and four servings a day in the second and third trimester of pregnancy. One glass of milk, yogurt, kefir, 100 grams of curd cheese or 2 slices of cheese is considered as one serving [20]. Our study revealed that only less than one third of patients followed these recommendations (29.6\%). This means that pregnant women eat dairy products in an insufficient amount, which may have an undesirable adverse effect on the course of pregnancy. Similar eating habits in relation to dairy products were presented by Kobiołka et al. [16]. Moreover, only about one fifth of pregnant patients consumed milk every day (23.2\%). Furthermore, $16.8 \%$ of our patients did not drink milk. Similarly, in the Mielnik's study [12] as much as $33 \%$ of women did not drink milk during gestation. Contrary, Kobiołka et al. [16] revealed that only $1 \%$ of pregnant respondents declared drinking of milk.

The basic products recommended in the daily diet of pregnant women are cereal products, being the main source of carbohydrates and minerals [22, 23]. Wholemeal bread, rich in fiber, regulates the motility of the digestive tract, gives a sense of satiety, which prevent snacking between meals, and thus creates a greater opportunity to maintain proper weight. Half of our respondents declared eating wheat bread and $24 \%$ of them chose wheat roll during pregnancy. Despite the large number of women who consumed wheat baking, a considerable amount of females chose wholemeal bread (49.2\%) and wholemeal rolls (35.6\%). Slightly worse nutritional habits were observed by Mielnik. The most of survey respondents chose wheat bread (48.9\%) and wheat roll (46.6\%). The rest of pregnant respondents ate wholemeal bread (29.5\%), wholemeal roll (20.5\%), wheat-rye bread (19.3\%), rye bread (14.8\%) and toasted bread (3.4\%) [12].

The positive association between consumption of fruit and vegetables and a birthweight was observed in previous studies [24-26]. Our respondents ate the most often apples, bananas and oranges, and the most often chosen vegetables were tomatoes, carrots and potatoes. The similar preferences were observed by Mielnik [12].

A lot of dietary behaviors were associated with education level. That's why education of pregnant patients regarding healthy nutrition is so important. Interestingly, only a few dietary preferences differed between patients after taking into account BMl and gestational weight gain. We assumed that differences between groups may not be statistically significant because all groups were composed of patients whose pre-pregnancy BMI was too low, normal or too high, therefore the differences of nutritional behaviors may be unnoticeable. In addition, the questionnaire referred to the consumption of food in pregnancy without specifying the consumed quantity. Dietary intake is difficult to measure but the meals quantity is one of the most important factors of the appropriate weight gain during pregnancy. The larger meal portions contribute to higher weight gain in pregnant women. The method of measurement of the food consumption should be easy and clearforall pregnant women. According to Nöthlings study [27], measuring food intake by cups, servings and grams is effective and adequate for most analyzes. Taking into account cups and servings may be much easier for most surveyed patients. In our study we decided that it would be difficult to determine because of probable differences between gestational trimesters, even within the same trimester and seasonal changes in meals composition. Anyway, the calculation of food intake should be consider in further studies.

Analyzing the dietary preferences data in pregnancy, it should be stated that many pregnant women do not follow the food recommendations. It has to be underline that there is a lot to do in this area. The principles of healthy eating based on the pyramid of healthy nutrition should be promoted among reproductive-aged women. Doctors and health professionals should be obliged to implement proper dietary behavior and inform about harmful effects of both malnutrition as well as overeating in pregnancy.

\section{CONCLUSIONS}

The study revealed that the most pregnant women consumed meals with adequate frequency. Moreover, we noticed the recommended consumption of meat with poultry preference. However, the dietary habits revealed nutritional mistakes such as low consumption of fish and dairy products, consumption of wheat breadstuff and sweets, as well as small intake of milk. The high education level was related with greater consumption of vegetables, yoghurt, beef, fish of best choices", wholemeal bread and eating five meals a day. The weight gain during pregnancy was associated with consumption of wholemeal bread, beef, herring, watermelon, eating between meals and eating meat in general. Therefore, there is still a considerable need to expand nutritional education and to develop mother awareness in the perinatal care programs. 


\section{REFERENCES}

1. Balarajan $\mathrm{Y}$, Ramakrishnan U, Ozaltin E, et al. Anaemia in low-income and middle-income countries. Lancet. 2011; 378(9809): 2123-2135, doi: 10.1016/S0140-6736(10)62304-5, indexed in Pubmed: 21813172.

2. Ramakrishnan U, Grant F, Goldenberg T, et al. Effect of women's nutrition before and during early pregnancy on maternal and infant outcomes: a systematic review. Paediatr Perinat Epidemiol. 2012; 26 Suppl 1: 285-301, doi: 10.1111/j.1365-3016.2012.01281.x, indexed in Pubmed: 22742616.

3. Gaillard R, Durmuş B, Hofman A, et al. Risk factors and outcomes of maternal obesity and excessive weight gain during pregnancy. Obesity (Silver Spring). 2013; 21(5): 1046-1055, doi: 10.1002/oby.20088, indexed in Pubmed: 23784909.

4. Leonard SA, Rasmussen KM, King JC, et al. Trajectories of maternal weight from before pregnancy through postpartum and associations with childhood obesity. Am J Clin Nutr. 2017; 106(5): 1295-1301, doi: 10.3945/ajcn.117.158683, indexed in Pubmed: 28877895.

5. Procter SB, Campbell CG. Position of the Academy of Nutrition and Dietetics: nutrition and lifestyle for a healthy pregnancy outcome. J Acad Nutr Diet. 2014; 114(7): 1099-1103, doi: 10.1016/j.jand.2014.05.005, indexed in Pubmed: 24956993.

6. Institute of Health. Nutrition during pregnancy. Washington DC 1990.

7. Arkkola T. Arkkola T. Diet during pregnancy. Dietary patterns and weight gain rate among Finnish pregnant women. Acta Universitatis Ouluensis. D, Medica 2009.

8. Bręborowicz GH, Ropacka-Lesiak M. Żywienie w czasie ciąży i połogu. In: Bręborowicz GH. ed. Położnictwo i ginekologia. Tom 1. Położnictwo. PZWL, Warszawa 2015: 73-83.

9. Bręborowicz GH, Ropacka-Lesiak M. Żywienie w czasie ciąży i połogu. In: Bręborowicz GH, Markwitz W. ed. Położnictwo. Tom 1. Fizjologia ciąży. PZWL, Warszawa 2012: 153-167.

10. Bręborowicz GH, Ropacka M. Żywienie kobiet ciężarnych i karmiących. In: Grzymisławki M, Gawęcki J. ed. Żywienie człowieka zdrowego i chorego. Tom 2. Wyd. 2. PWN, Warszawa 2010: 62-79.

11. Ropacka M. Żywienie kobiet ciężarnych. In: Bręborowicz GH. ed. Położnictwo i ginekologia. PZWL, Warszawa 2005: 67-75.

12. Mielnik A. Stężenie kwasu foliowego i homocysteiny w surowicy krwi pępowinowej w zależności od wybranych czynników środowiskowych. Rozprawa doktorska 2017.

13. Institute of Medicine. Nutrition During Pregnancy and Lactation. 1992, doi: $10.17226 / 1984$

14. Siega-Riz AM, Herrmann TS, Savitz DA, et al. Frequency of eating during pregnancy and its effect on preterm delivery. Am J Epidemiol. 2001; 153(7): 647-652, doi: 10.1093/aje/153.7.647, indexed in Pubmed: 11282791.
15. Pieszko M, Ciesielska-Piotrowicz J, Skotnicka M, et al. Behaviour health pregnant women with secondary and higher education - preliminary studies. Pediatria i Medycyna Rodzinna. 2017; 13(1): 94-102, doi: 10.15557/pimr.2017.0009.

16. Kobiołka A, Goraus M, Mężyk I, et al. Wpływ ciąży na zmianę nawyków żywieniowych kobiet w wieku rozrodczym. Zdrowie i dobrostan. 2015; 2(13): 187-205

17. Krzyszycha R, Bień AM, Grudzińska M. Dieta kobiety ciężarnej. Zapotrzebowanie na składniki odżywcze i ich rola w organizmie kobiety ciężarnej. In: Bień AM. ed. Opieka nad kobietą ciężarną. PZWL, Warszawa 2009: 225-230.

18. Rekomendacje Zarządu Głównego Polskiego Towarzystwa Ginekologicznego w zakresie opieki przedporodowej w ciąży o prawidłowym przebiegu. Ginekol Dypl. 2008; 10: 191-196.

19. Kułaga Z, Grajda A. Profilaktyka otyłości od poczęcia. Standardy medyczne/ Profilaktyka zdrowotna. 2015; 1: 23-40.

20. Szostak-Węgierek D, Cichocka A. Żywienie kobiet ciężarnych. 2nd ed. PZWL, 2012.

21. US Food and Drug Administration \& US Environmental Protection Agency. Eating fish: what pregnant women and parents should know. http://www.fda.gov/ downloads/Food/FoodbornelllnessContaminants/Metals/ UCM537120.pdf (10.2017).

22. Szostak-Węgierek D. Znaczenie prawidłowego żywienia kobiety w czasie ciąży. Żyw Człow. 2004; 31(2): 160-171.

23. Raczyński P, Kubik P, Niemiec T. Zalecenia dotyczące suplementacji diety u kobiet podczas planowania ciąży, w ciąży i w czasie karmienia piersią. Ginek Prakt. 2006; 14(4): 2-7.

24. Mikkelsen TB, Osler M, Orozova-Bekkevold I, et al. Association between fruit and vegetable consumption and birth weight: a prospective study among 43,585 Danish women. Scand J Public Health. 2006; 34(6): 616 622, doi: 10.1080/14034940600717688, indexed in Pubmed: 17132595.

25. Ramón $R$, Ballester $F$, Iñiguez $C$, et al. Vegetable but not fruit intake during pregnancy is associated with newborn anthropometric measures. J Nutr. 2009; 139(3): 561-567, doi: 10.3945/jn.108.095596, indexed in Pubmed: 19158218.

26. Rao S, Yajnik CS, Kanade A, et al. Intake of micronutrient-rich foods in rural Indian mothers is associated with the size of their babies at birth: Pune Maternal Nutrition Study. J Nutr. 2001; 131(4): 1217-1224, doi: 10.1093/jn/131.4.1217, indexed in Pubmed: 11285330.

27. Nöthlings U, Murphy SP, Sharma S, et al. A comparison of two methods of measuring food group intake: grams vs servings. J Am Diet Assoc. 2006; 106(5): 737-739, doi: 10.1016/j.jada.2006.02.006, indexed in Pubmed: 16647334.
Supplemental file 1. The questionnaire

\begin{tabular}{|l}
\hline $\begin{array}{l}\text { Part I - demographic data (please highlight the correct } \\
\text { answers) }\end{array}$ \\
\hline Age ................... \\
\hline Body weight before pregnancy ................... \\
Current body weight ................... \\
\hline Height .................. \\
\hline Place of residence \\
\hline rural area less than 5000 people \\
\hline small city less than 20,000 people \\
\hline city more than 20,000 people \\
\hline Monthly household income without taxes \\
\hline less than 1,000 PLN \\
\hline $1,100-3,000$ PLN \\
\hline 3,100-6,000 PLN \\
\hline $6,100-10,000$ PLN \\
\hline more than 10,000 PLN \\
\hline
\end{tabular}

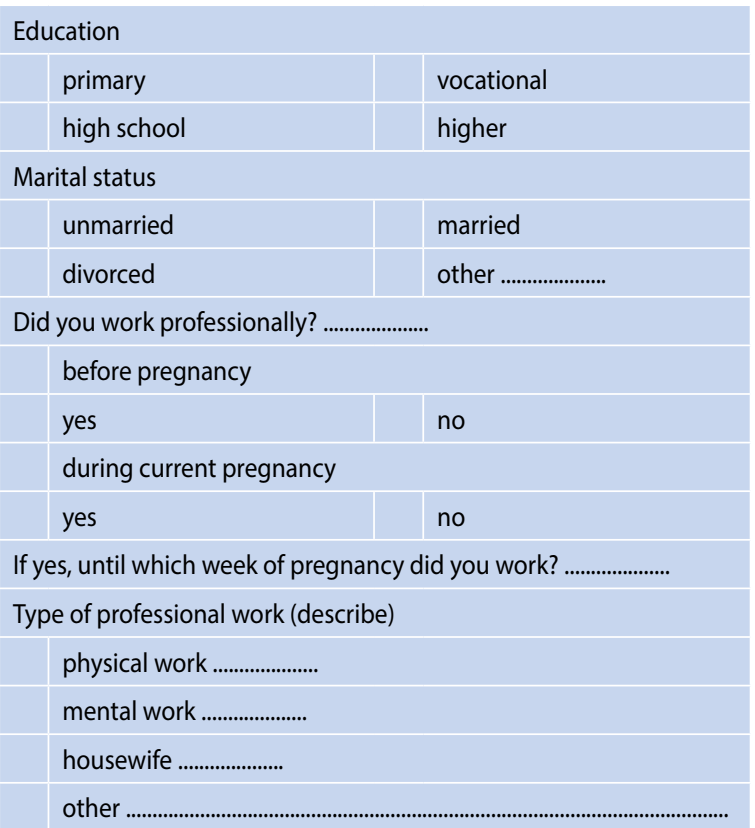




\begin{tabular}{|c|c|}
\hline \multicolumn{2}{|c|}{ In which area are you employed? } \\
\hline agriculture & food industry \\
\hline textile industry & construction \\
\hline hotel and gastronomy & transport \\
\hline finance and banking & media, publishing \\
\hline advertising & \\
\hline \multicolumn{2}{|c|}{ information technology, telecommunications } \\
\hline public administration & education \\
\hline health service & social assistance \\
\hline culture, entertainment & recreation \\
\hline \multicolumn{2}{|c|}{ 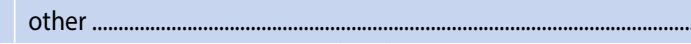 } \\
\hline \multicolumn{2}{|c|}{ Type of the work (you can choose more than one answer) } \\
\hline \multicolumn{2}{|c|}{ sitting, about 4 hours per day } \\
\hline \multicolumn{2}{|c|}{ sitting, about 8 hours or more per day } \\
\hline \multicolumn{2}{|c|}{ physical, less than 4 hours per day } \\
\hline \multicolumn{2}{|c|}{ physical, about 8 hours or more per day } \\
\hline \multicolumn{2}{|c|}{ work mostly related with driving } \\
\hline \multicolumn{2}{|l|}{ student } \\
\hline \multicolumn{2}{|l|}{ unemployed } \\
\hline \multicolumn{2}{|c|}{$\begin{array}{l}\text { What is the main source of the stress for you in your work? (choose } \\
\text { maximum } 3 \text { answers) }\end{array}$} \\
\hline \multicolumn{2}{|c|}{ conflicts between employees } \\
\hline \multicolumn{2}{|c|}{ conflicts with management } \\
\hline \multicolumn{2}{|c|}{ problems with defining the responsibilities } \\
\hline \multicolumn{2}{|l|}{ sense of control } \\
\hline \multicolumn{2}{|c|}{ workload } \\
\hline \multicolumn{2}{|c|}{ possibility of self-realization and the use of own potential } \\
\hline \multicolumn{2}{|l|}{ conflict of values } \\
\hline \multicolumn{2}{|l|}{ health } \\
\hline \multicolumn{2}{|c|}{ physical working conditions } \\
\hline \multicolumn{2}{|c|}{$\begin{array}{l}\text { What is the main source of the stress for you in your family life? } \\
\text { (choose maximum } 3 \text { answers) }\end{array}$} \\
\hline \multicolumn{2}{|c|}{ conflicts with your spouse/partner } \\
\hline \multicolumn{2}{|c|}{ conflicts with other family members } \\
\hline \multicolumn{2}{|c|}{ health of family members } \\
\hline \multicolumn{2}{|l|}{ financial problems } \\
\hline \multicolumn{2}{|l|}{ work } \\
\hline \multicolumn{2}{|c|}{ division of duties (cleaning, babysitting) } \\
\hline \multicolumn{2}{|l|}{ conflict of values } \\
\hline political views & \\
\hline other & \\
\hline
\end{tabular}

Part II - questions about general health and obstetric history (please write or highlight the correct answer)

\section{Obstetric history}

labors

period between current and last pregnancy (years)

miscarriages

Week of gestation

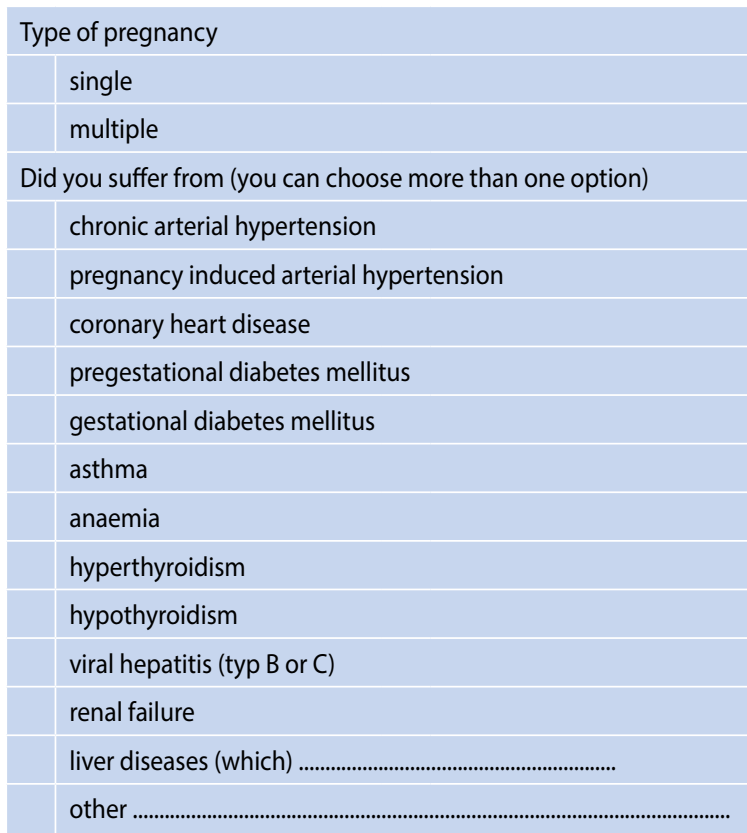

Did you suffer from any other pregnancy complication: (several answers are possible)

polyhydramnion

oligohydramnion

premature rupture of membranes) (which week of pregnancy?

......................

intrauterine growth restriction

complications of multiple pregnancy (twin-to-twin transfusion syndrome, selective intrauterine growth restriction)

fetal defect

genetic fetal defect

cervical insufficiency, did you have cervical suture? If yes, in

which week of pregnancy?

threatening preterm delivery

threatened miscarriage

intrauterine infection

bleeding

abdominal pain

abnormality of placenta or umbilical cord: placenta increta

vasa previa, umbilical cord collision

other

Did you have the back pain during pregnancy?

yes

no

When did the back pain occur first time? (week of gestation)

In which part of spine did a pain occur? (multiple choice)

cervical

thoracic

lumbar

pelvic

all 


\begin{tabular}{|c|c|}
\hline \multicolumn{2}{|l|}{ Did a pain awake you? } \\
\hline \multicolumn{2}{|l|}{ yes } \\
\hline \multicolumn{2}{|l|}{ no } \\
\hline \multicolumn{2}{|l|}{ Did you have hands oedema? } \\
\hline \multicolumn{2}{|c|}{ yes, in which week of pregnancy? ...................... } \\
\hline \multicolumn{2}{|l|}{ no } \\
\hline \multicolumn{2}{|l|}{ Did you have legs oedema? } \\
\hline \multicolumn{2}{|c|}{ 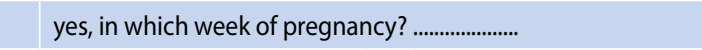 } \\
\hline \multicolumn{2}{|l|}{ no } \\
\hline \multicolumn{2}{|c|}{$\begin{array}{l}\text { Was there a time during the day when the back pain was stronger } \\
\text { (Multiple choice) }\end{array}$} \\
\hline morning, just after awake & morning \\
\hline early afternoon & afternoon \\
\hline evening & whole day \\
\hline \multicolumn{2}{|l|}{ at night } \\
\hline
\end{tabular}

\section{Part III - nutritional behaviors during pregnancy (please highlight the correct answer)}

Were you on any special diet?

no

vegetarian

vegan

other, what?

How many meals did you have every day (without sweets)

\begin{tabular}{|l|l|l|}
\hline one & two \\
\hline three & four \\
\hline five & more than five \\
\hline What did you eat between main meals? \\
\hline fruits, vegetables \\
\hline yoghurt \\
\hline sweets \\
\hline sandwiches \\
\hline sweet buns \\
\hline other, what? ............................................................................................. \\
\hline I don't eat between meals \\
\hline
\end{tabular}

What kind of bread did you eat the most often (choose maximum 2 answers)

\section{wheat bread \\ wholemeal bread \\ rye bread \\ wheat rolls \\ wholemeal rolls \\ crispy bread \\ I don't eat bread}

What fruits were you most likely to eat (choose maximum 3 options)

\begin{tabular}{|l|l|l|}
\hline apples & strawberries \\
\hline grapes & plums \\
\hline raspberries & cherries \\
\hline bananas & oranges \\
\hline
\end{tabular}

\begin{tabular}{|l|l|l|}
\hline \multicolumn{1}{|l|}{ peaches or apricots } & watermelons \\
\hline \multicolumn{1}{|l|}{ lemons } & \multicolumn{1}{l|}{ grapefruits } \\
\hline $\begin{array}{l}\text { What vegetables were you most likely to eat (choose maximum } \\
\text { 3 options) }\end{array}$ \\
\hline potatoes & carrots \\
\hline parsley & broccoli \\
\hline cauliflower & asparagus \\
\hline celery & tomatoes \\
\hline cucumbers & onions \\
\hline
\end{tabular}

What kind of meat did you eat most often during pregnancy?
poultry
beef
veal
other, what?
I didn't eat meat during pregnancy

What kind of fish did you eat most often during pregnancy?
salmon
carp
cod
zander
mackerel
herring
pollock
panga
hake
other, what?
I didn't eat fish during pregnancy

How often per week did you eat fish as main meal?

once a week

twice a week

3 times a week

4 times a week

five or more than 5 times a week

I didn't eat fish at all

How often did you eat meat and sliced meats?

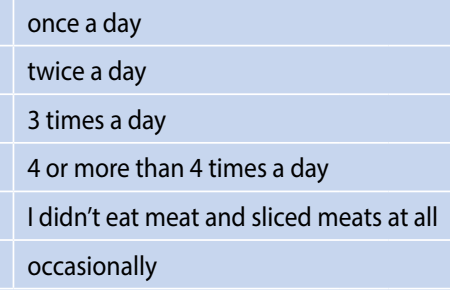

How often did you eat dairy products?

\begin{tabular}{|l}
\hline once a day \\
\hline twice a day \\
\hline 3 times a day \\
4 or more than 4 times a day \\
\hline I didn't eat dairy products \\
\hline occasionally \\
\hline
\end{tabular}

